Article

\title{
The Presbyterian Church and Zionism Unsettled: Its Antecedents, and Its Antisemitic Legacy
}

\author{
Cary Nelson \\ English Department, University of Illinois at Urbana-Champaign, Urbana, IL 61801, USA; crnelson@illinois.edu
}

Received: 30 May 2019; Accepted: 20 June 2019; Published: 22 June 2019

\begin{abstract}
The new millennium has seen increased hostility to Israel among many progressive constituencies, including several mainline Protestant churches. The evangelical community in the US remains steadfastly Zionist, so overall support for financial aid to Israel remain secure. But the cultural impact of accusations that Israel is a settler colonialist or apartheid regime are nonetheless serious; they are proving sufficient to make support for the Jewish state a political issue for the first time in many decades. Despite a general movement in emphasis from theology to politics in church debate, there remain theological issues at the center of church discussion. The Protestant church with the longest running and most well-funded anti-Zionist constituency is the Presbyterian church in the US. In the last decade, its Israel/Palestine Mission Network (IPMN) has produced several increasingly anti-Zionist books designed to propel divestment resolutions in the church's annual meeting. The most widely debated of these was 2014's Zionism Unsettled: A Congregational Study Guide. This essay mounts a detailed analysis and critique of the book which documents the IPMN's steady movement toward antisemitic positions. Among the theological issues underlying debate in Protestant denominations are the status of the divine covenant with the Jewish people, the role that the gift of land has as part of that covenant, and the nature of the characterization of the Jews as a "chosen people". These, and other issues underlying Protestant anti-Zionism, have led to the formation of Presbyterians for Middle East Peace (PFMP), a group, unlike IPMN, that supports a two-state solution. The competing positions these groups have taken are of interest to all who want to track the role that Christian denominations have played in debates about the Israeli-Palestinian conflict.
\end{abstract}

Keywords: Presbyterian church; Zionism; BDS; chosenness; covenant

\section{Introduction: The Prehistory of Recent Presbyterian Debates}

The new millennium has seen a dramatic increase in intense hostility to Zionism and the Jewish state, hostility that both in its arguments and in its intensity sometimes crosses a line into antisemitism. Whatever its multiple historical incarnations, Zionism at its core was a movement to establish a homeland for the Jewish people. That core purpose was realized when Israel was founded in 1948, and it rendered many earlier disputes about how to define Zionism moot. It also focused the meaning of anti-Zionism on opposition to Israel's existence. No longer embodying just a theoretical question about the Jewish people's right to political self-determination, anti-Zionism became a challenge to citizens' political rights in an actually-existing Jewish state. Currently, over six million of those citizens are Jews.

Anti-Zionist and antisemitic features of the Boycott, Divestment, and Sanctions movement (BDS), whether widely acknowledged or not, are at least widely debated. But a new religious antisemitism is far less well known outside the relevant Christian denominations. Even there, however, detailed knowledge of denominational anti-Zionism remains mostly within individual denominations, though representatives of anti-Zionist organizations commonly participate in multiple denominations' annual meetings. Finally, the resolutions passed by Methodist, Presbyterian, and other denominations' annual meetings are widely covered by the press, but actual knowledge of key anti-Zionist books by church 
activists is relatively little-known. This essay will concentrate on publications by the anti-Zionist wing of the PC (USA), the US Presbyterian church. The essay is part of a book in progress, Peace and Faith: Christian Churches and the Israeli-Palestinian Conflict, being edited by myself and Michael Gizzi, which will include an expanded version of the present piece in a cluster of several essays about Presbyterian anti-Zionism, along with discussions of Catholic, Methodist, and Mennonite anti-Zionism, and the relevant history of antisemitism. The book will also address the largest pro-Israel Christian group in the United States, the evangelical community.

In 2014, a voluntary advocacy group within the PC (USA), the anti-Zionist Israel/Palestine Mission Network (IPMN), launched a three-pronged anti-Zionist publication campaign designed to cement opposition to Israel within the church and promote divestment resolutions at its upcoming annual meeting. Described in greater detail below, the 2014 publications at issue comprised two books-Zionism Unsettled: A Congregational Study Guide, hereafter ZU, and Zionism and the Quest for Justice in the Holy Land, hereafter Quest, along with an elaborate nine-part open access video series. The "study guide" model had been used by the church for nearly fifty years as a way to address the Israeli-Palestinian conflict, though IPMN replaced earlier efforts to raise questions for discussion with a determination to supply answers, answers that arguably cross a line into antisemitism. The publications are part of perhaps the single most extensive anti-Zionist campaign of any among Christian groups in the US. The anti-Zionist campaign within the PC (USA) is certainly the most well-established and also the best funded campaign of those in the Protestant churches. As I will try to show, part of the legacy of the 2014 effort was to prepare the ground for the more overtly antisemitic 2018 IPMN book, Why Palestine Matters: The Struggle to End Colonialism (Israel/Palestine Mission Network of the Presbyterian Church (USA)).

The historical roots of recent Presbyterian debates run deep, since the church has been involved in missionary work in Palestine for over a hundred and fifty years. While the church never succeeded in converting Muslims, it did become part of Arab culture and in time allied itself with anti-colonialism in the region. As Fishman (1973) writes, "Because the (American Protestant) missionaries provided political support for the Arab cause, they inevitably became opponents of Jewish nationalism in Palestine". They "invariably supported the battle against Zionism" (p. 179), and the Presbyterians as a consequence were often referred to as a pro-Arab church. Yet opposing views then and now continue to divide the denomination.

As Hopkins (1990) points out, a split developed between the missionaries (now called "fraternal workers") and those Presbyterian leaders in the US who were focused on interfaith alliances with the Jewish community, alliances that were strengthened by relationships built on shared commitments to the civil rights movement and to anti-Vietnam protest. The divisions were exacerbated in the wake of the 1967 war and the emergence of the occupation as an issue.

A report presented by a Middle East Task Force to the PC (USA) meeting in 1972, "Peoples and Conflict in the Middle East", confirmed that "the Abrahamic covenant is unconditional in that it is not based on the prior acts of the people nor can it be invalidated by any sin of the people" (p. 32), theological positions that IPMN decades later would explicitly reject. Indeed, the report emphasizes the contemporary connection: "the current state of Israel may be viewed as a sign of the continuing relationship of God with the Jewish people". Past efforts to claim the covenant was broken, it adds, are evidence of antisemitism within the church. At the same time, the report declares what remains true about the West Bank: "Palestinians do not enjoy rights in any degree consistent with modern political standards" (p. 42).

Two years later the balance had shifted only modestly. The Task Force's 1974 88-page report, "The Middle East Conflict", for the first time recognized a Palestinian right to self-determination and reformulated the church's reasoning behind the centrality of reconciliation: "To ignore injustices that have been commonplace is not reconciliation. A people 'reconciled' to its own suffering and humiliation is not truly reconciled" (p. 8). 
But events were leading the church to add criticism of Israel to its balanced commitments to political goals. The mid-1970s saw a settler movement evolve in the West Bank. The Palestine Liberation Organization meanwhile, was succeeding in building political self-identification among the refugees. Then, in 1988, the annual meeting of the church reacted to the First Intifada by urging Israel to "cease the systematic violation of human rights of Palestinians in the occupied territories". A line had been crossed.

One significant consequence of the emerging dominant leadership view, despite widespread pro-Zionist sentiment among the Presbyterian laity, was the eventual election of anti-Zionist members as moderator, head of the denomination's policy-setting annual meeting, its General Assembly. In 2002, in the wake of two events- the World Conference on Racism in Durban, South Africa, that promoted the "Zionism is Racism" thesis, and the Second Intifada—an intensely anti-Zionist Palestinian, Fahed Abu-Akel, was appointed moderator. That helped lead to passage of a 2003 resolution calling on Israel to End the Occupation Now. At the following year's General Assembly, the anti-Israel forces coalesced, established the IPMN, and pushed forward a divestment resolution. In response, Presbyterians who support the existence of a Jewish state came together to found Presbyterians for Middle East Peace (PFMEP), a group that was fully organized and functioning prior to the 2008 General Assembly.

\section{Zionism Unsettled and the 2014 General Assembly Meeting}

The presence of two competing groups-IPMN and PFMEP-made for a notably contentious meeting in June 2014. Nonetheless, the IPMN forces were able to impose one-sided procedures that blocked open debate and promoted their anti-Zionist agenda. They succeeded in passing a resolution by a vote of 310-303 to divest from Caterpillar, Motorola Solutions, and Hewlett-Packard, companies the PC (USA) deemed complicit in and profiting from Israel's occupation of the West Bank and blockade of Gaza. In response, more than 40 Commissioners to and Observers of the PCUSA's General Assembly signed Reformed and Reforming: A Word of Hope, a pamphlet decrying unfair and one-sided procedures at the 2014 meeting (Commissioners to and Observers of the 221st General Assembly of the PC (USA)). The debate, they conclude, "in essence has become within the PC (USA) a Middle East war of proxy over the last decade" (p. 6) in which "the denomination's historic commitment to fair and open debate of crucial issues" has been set aside (p. 15).

A number of outside groups and speakers had a major impact on the PC (USA) process. BDS activist Dalit Baum, who is director of the American Friends Service Committee's Economic Activism Program, helped the PC (USA) justify divestment. Jewish Voice for Peace (JVP) and Sabeel were active at the meeting. The connection with the Sabeel Ecumenical Liberation Theology Center in East Jerusalem is particularly significant because Friends of Sabeel North America, one of its many national chapters, collaborates with IPMN on its publications. Founded by Anglican priest Naim Ateek in 1989, Sabeel has promoted a version of supersessionism — the belief that Christianity replaced or invalidated, thereby "superceded" the special relationship between the Jews and god-that is linked with Palestinian liberation politics. ${ }^{1}$ Ateek writes widely on Palestinian Liberation Theology and

1 What is arguably the first supersessionist text, the Epistle of Barnabas, was composed about 132 CE. The Epistle, which ultimately was not included in the canon of the New Testament, asserts that Christians are the only true covenant people and that the Jewish covenant with God has ended. Though not yet named, supersessionism, the logic that Christians have replaced Jews as God's chosen community, solidified during the second and third centuries as the Church's dominant perspective. It would be equally defining in Protestant denominations after the Reformation. Negative portrayals of Jews begin to become a way to define Christian identity and the meaning of Christianity against Judaism, as Christianity relies on a fantasy Judaism to define it as its polar opposite. Even apparently less-hostile figures would strengthen the tradition. Immensely influential, Augustine's views helped keep Jews alive in some contexts, but they also established a status that put Jews in peril in others. "Augustine's relatively benign attitude toward Jews is rooted still in assumptions of supersessionism that would prove to be deadly. The 'witness' prescription attributed to him-Let them survive, but not thrive!-would underlie the destructive ambivalence that marked Catholic attitudes toward Jews from then on. Ultimately, history would show that such a double-edged ambivalence is impossible to sustain without disastrous consequences" (Carroll 2001, p. 219). 
promotes the idea that Palestinians are being "crucified" on the cross of Israeli policy, rhetoric that invokes the ancient antisemitic accusation of deicide.

The 2014 IPMN campaign and its three publication components are of interest not only in themselves but also because their anti-Zionism embodies both the ideology of the BDS movement as a whole and the sometimes-distinctive convictions that have driven divestment and boycott initiatives in other Christian denominations. Zionism Unsettled: A Congregational Study Guide (Israel/Palestine Mission Network of the Presbyterian Church (USA)), is a large-format, full color, heavily illustrated 74-page book-length publication coordinated by Walter T. Davis, an emeritus professor of Sociology and Religion and a former director of the Advanced Pastoral Studies Program at San Francisco Theological Seminary in San Anselmo, California. Released in January 2014, ZU was itself drawn in part from the full-length book Zionism and the Quest for Justice in the Holy Land, edited by Davis and Donald E. Wagner (Wagner and Davis 2014), a professor and director of the Center for Middle Eastern Studies at North Park University in Chicago, both are Presbyterians and emeritus faculty members. Quest was not likely widely available until the month after the June 2014 meeting.

$\mathrm{ZU}$ was coordinated with the video series that has a total running time of $198 \mathrm{~min}$.

The entire three-part project is marketed as an integrated course on the history, theology, and current politics underlying the Israeli-Palestinian conflict. The word "Unsettled" in the title has a dual meaning, expressing the aim of destabilizing or unsettling the Zionist project and of stripping the Holy Land of all Jewish settlements, hence "unsettling" it. In order to make it clear that the project constitutes a collective, consensual document issued jointly with Friends of Sabeel North America and not simply a collection of opinion pieces by individual authors, the names of the authors of individual chapters in the guide do not appear either in the table of contents or with the title of each chapter, but rather in a footnote in reduced type at the bottom of the opening page of the individual sections.

Each of the nine sections has two parts, except for the last, which has three. The second topic in each section is an unsigned "Focus" page. None of the brief published commentaries on $\mathrm{ZU}$ has addressed the structure of the book, which is one of the reasons I reproduce the table of contents here. People familiar with secular debates about the Israeli-Palestinian conflict will note that several of the chapter titles highlight religious interests different from those that occupy secular BDS initiatives. But the authors of $Z U$ were clearly challenged to integrate, rather than juxtapose (as with chapters two and five), religious and secular concerns: Chapter titles are in bold: 1 . Toward a New Framework/Palestine, Israel, and the United Nations//2. Political Zionism/Constantinian Religion//3. The Concept and Practice of a Jewish State/A Tale of Two Villages//4. Christian Views of Jews and Judaism/The Covenant//5. A Jewish Theology of Liberation/Extremism and Intolerance in Israel//6. Mainline Liberal Protestants and Israel/Israel's "Image Problem"//7. Evangelicals and Christian Zionism/What Diaspora?//8. A Palestinian Muslim Experience with Zionism/Memoricide//9. A Palestinian Christian Postscript/Emerging from the American Jewish Cocoon/“Judaizing" the Land. One could argue that a seamless integration of secular and theological issues would have been stronger, but the authors opt instead to appeal to different Protestant constituencies separately.

\section{The Biblical Covenant with Israel}

Although debates over the meaning and application of Old and New Testament texts have not had wide influence outside Christian and Jewish faith communities, in those communities at least they have long been in either the foreground or the background of the arguments people bring to their understanding of the Israeli-Palestinian conflict. With the exception, perhaps, of the evangelical community, however, politics has gradually displaced theology at the core of many contemporary Christian debates. Over the last generation it seems that it is increasingly those who oppose contemporary Zionism, rather than those who endorse all but the most religiously-based versions of it, who are most likely to invoke God's biblical covenant to grant the holy land to the Jewish people. 
Since the early history of the Church, in an argument since abandoned by most major Christian denominations, supersessionist theologians have argued that God's covenant with Israel was effectively ended by Christ's life and crucifixion and that the Church has now inherited it. Or they have focused on the possibility that the covenant was conditional, dependent on the Jewish people adhering to God's law, an argument that survives in contemporary suggestions that Israel's current conduct means the covenant is still open to being revoked. Some have promoted a version of Christian universalism, suggesting that the covenant actually addressed all lands and all peoples, not some particular piece of Middle Eastern territory.

The 1973 Presbyterian report cited earlier states firmly that "The Abrahamic and Davidic covenants speak not of a spiritual bond nor of oneness based on ethical norms, but of a particular people linked to the Land as a result of God's promise" (p. 34). This "particularism" was long used as a justification for antisemitic violence. The debates promoted by Palestinian liberation theology have also insisted that Zionists persist in claiming a divine warrant for the existence of the Jewish state. Moreover, IPMN suggests that Israelis today overwhelmingly assert the applicability of a divine covenant, which is more than misleading, it is not true. While it might seem that the fundamentally secular character of the Zionist movement presents an obstacle to this claim, it in fact makes it possible for IPMN to mount a conspiratorial and antisemitic theory about how secular Zionists cynically used invocations of God's covenant to promote a takeover of Palestinian land. The authors of $Z U$ mention that Palestinian Christian "Mitri Zaheb refers to this practice by secular Zionists as an effort to intentionally 'brand' the State of Israel as a 'biblical entity'" (p. 22). A ZU focus page on "The Covenant" expands on the Zionist conspiracy: "By linking the Zionist political project to prophetic 'promises,' many Jewish and Christian believers could be led to accept the Jewish state-building project as not emerging from the human mind, but God's" (p. 31). A quotation from Ilan Pappe seals the indictment: "'they did not believe in God but He nonetheless promised them Palestine'" (p. 31). In other words, faithless Jews duped innocent Christians into applying an ancient religious story to contemporary life. "Yes", ZU emphasizes, "the Bible tells us of God's activity in covenanting with Israel, but it was ancient Israel, not the modern political State" (p. 66).

Readers of $Z U$ will look in vain if they seek any evidence that this plot to deceive Christians ever existed, and IPMN does not cite examples of Israeli land policy defended with biblical justifications. But the assertion does useful work in IPMN's project nonetheless, not only as part of an ongoing campaign to disparage Christian Zionists, though that is one of its aims. For it makes it possible to suggest that the Jewish state is paradoxically the new pagan Rome, an embodiment of "idolatrous political nationalism'" (p. 33). In this way, the anti-Zionist campaign comes full circle: Zionism created a secular state that falsely claims theological warrant for its existence, but since it is in fact a community of nonbelievers-only a quarter of Israeli Jews are devout—we can understand how a faux Jewish state could betray true Jewish values of fairness and equality. No better set of false assumptions could be found for asserting that anti-Zionism is not antisemitic.

\section{Representative Factual Errors in Zionism Unsettled}

While the effort to lay the blame for the Israeli-Palestinian conflict at the feet of Zionist ideology is the IPMN project's main focus, that goal is grounded in a series of false historical claims. Several are deceptively offered as factual asides that uninformed readers are unlikely to question. Thus, for example, the first "Focus" section baldly informs us that in 1947 "at the time of partition Palestinian Arabs owned approximately $93 \%$ of the land in Palestine, Jews $7 \% "$ (p. 10). This figure is a complete fabrication and should not have been endorsed and promoted by a religiously-affiliated group.

Although real estate records in Palestine were poorly documented, no one who has read much about the matter is unaware that a substantial part of Palestine was not private property. It was controlled by the Ottoman Empire until the empire was defeated in World War One. In 1922 that land fell under the administrative control of the British Mandate until the 1947 UN vote that created the 
Jewish state, at which point it was inherited by Israel. The British Survey of Palestine, dating from 1945-1946, reports that at least 65 percent of Palestine was such state-owned land.

$Z U^{\prime}$ 's falsification of the data is graphically-reinforced when it reproduces the notorious set of maps showing what purport to be the main stages of Israeli land takeover, beginning with a 1946 "map" that shows virtually all of Palestine in green identified as "Palestinian land". Of course, the presentation of this fabricated data serves $Z U$ 's argumentative interest: convincing the reader that the creation of the Jewish state was fundamentally unjust. Indeed, the effect is to suggest that the "sin of occupation" (p. 35) begins decades before Israel conquered the West Bank in 1967, predating the 1948 creation of the Jewish state and embodied in fully legal Jewish land purchases since the late 19th century. Did Palestinian Arabs own more land than Jews in 1948? Yes, according to a 2013 data review funded by an Arab-Jewish group generally critical of Israeli land policy, Palestinian Arabs owned between 21 and 28 percent of Palestine, but far from the exaggerated 93 percent proportion IPMN would have us believe was the case.

A few pages later, $Z U$ invokes the supposed fact that "war broke out between Jewish and Arab forces when Israel declared independence in May 1948" (p. 14). The fact that the 1948 war began when the new state was attacked by Egypt, Iraq, Jordan, Lebanon, and Syria is conveniently omitted. Matters arguably get worse when Walter Davis and Pauline Coffman state in Zionism and the Quest for Justice in the Holy Land that "the Arab armies never attacked Israel proper (that is, the area allotted by the UN for a Jewish state), but restricted their military activities to the defense of that portion of Palestine that the UN had allotted for an Arab state" (p. 22).

The definitive study of the war is Morris (2008)'s 1948: A History of the First Arab-Israeli War, which is the source I use. The Davis/Coffman passage allows us not only to suppose that some high legal principle was at issue in the Arab conduct of the war but also that the Arabs invaded both to protect the Palestinian Arabs and to defend the UN's partition standard. While popular Arab opinion was inflamed by the pleas for help by Palestinian Arabs, the leaders of the Arab states each had land conquest and the expansion of their own national territory in mind. Had they been better organized and met less Jewish resistance they certainly would have eliminated Israel altogether.

When an Egyptian armored column started moving northward along the Mediterranean coast on 15 May 1948, Israelis certainly understood the Egyptian aim to be the elimination of the new Jewish state and Tel Aviv to be the ultimate target. Indeed, the Egyptian air force bombed Tel Aviv in May and June. The kibbutzim the Egyptians attacked along the way were not determined by their location in relation to partition, but rather their location on their invasion route. When the Iraqi forces attacked the Coastal Plain settlement of Geulim on May 28 they were, contrary to the fiction promoted by IPMN, within the area ceded to Israel by the UN partition plan. They were also less than ten miles from the Mediterranean, which meant Israel was in danger of being cut in two. Jordan violated the UN plan by occupying East Jerusalem, including the Jewish Quarter in the Old City. The UN plan had Jerusalem as an internationally administered city. IPMN's authors ignored the most well-researched academic historical studies whenever they found an outlying opinion that matched their political convictions.

\section{Zionism Unsettled's Polemical Agenda}

There are two somewhat distinct topics to address here-the project's overall aims and strategies and its numerous specific errors and misleading claims. In the end, even rigorously faith-based efforts have to make strategic decisions about issues, arguments, rhetoric, spokespersons, and images if they are to produce books and videos. They should monitor their ideological impulses so as to recognize when fact-checking is necessary to avoid succumbing to confirmation bias when deciding whether to validate a given assertion. $Z U^{\prime}$ 's editors failed to honor that principle fully, and the project as a result becomes a propaganda enterprise.

One way that happens is to cite a previous author's undocumented opinion as though it is now an established fact, something the authors of Zionism Unlimited do repeatedly. Fact-checking within the echo chamber of anti-Zionist opinion will not suffice. And $Z U$ 's authors did not even have the fig 
leaf of a university press peer review process as cover. Zionism Unlimited is structured by strategic decisions, misrepresentations, and factual errors that will not be readily apparent to those who are not dedicated students of the Israeli-Palestinian struggle.

One strategic decision was the choice to make only one reference to the BDS movement in the entire ZU book (p. 35), a decision in keeping with IPMN's wish at the time to make itself appear as an independent effort, despite the fact that the project throughout is in harmony with, and in complete support of, the BDS agenda that IPMN had embraced for years. That reluctance matches the Church's effort to differentiate its boycott resolutions from the BDS movement. In Quest, Wagner characterizes this as merely a Protestant effort to "utilize BDS strategies (boycott, divestment, and sanctions) or similar economic leverages" (p. 170), "among the instruments of nonviolence that are capable of promoting peaceful change in societies that resist justice" (p. 172), a global claim about Israel that draws no distinction between current government policy and the rest of Israeli society and its institutions. That one reference in ZU, moreover, comes in a quotation from Rabbi Brant Rosen's essay in Quest in which he says the BDS movement, as embodied in Jewish Voice for Jewish Voice for Peace (2017) and multiple Protestant denominations, is "challenging the American Jewish establishment's Constantinian hegemony on Israel". In a 2017 essay written for the JVP collection On Antisemitism, Walt Davis claims that "the Zionist ideological narrative" and its consequences for Palestinians "makes BDS necessary" (p. 21).

The "Constantinian" modifier invokes the merging of religion and state power and draws on the second "Focus" page, "Constantinian Religion" (p. 16), which cites Carroll (2001)'s Constantine's Sword, a ground-breaking account of the Catholic Church's long history of promoting anti-Judaism with antisemitic consequences. Interviews with Carroll occupy part of episode four of the companion video as well. The moment when Roman Emperor Constantine converted to Christianity, which led to Christianity becoming a state religion with the power to enforce its views and sanction heretics, is transformative, the cross came to double as a sword, a weapon. ZU's authors find one fault in Carroll's account: its "expose is incomplete because it errs, like many well-intentioned partners in the 'ecumenical deal,' in failing to recognize that Israeli policies are also an expression of 'Constantinian religion"' (p. 16). But Israeli policies are not grounded in theological conviction, nor do secular Israelis see the Jewish state as the realization of a divine covenant.

ZU does review Christianity's anti-Jewish history of "forced conversion, exclusion, execution, humiliation, caricature, ghettoization, pogroms, and genocide" (p. 25) in chapter four, "Christian Views of Jews and Judaism" (pp. 25-30). But ZU arrives in the wake of decades of Catholic and Protestant reconciliation efforts with Jews, including the Catholic Church's historic 1965 statement Nostra Aetate, a declaration that marked the Church's break with centuries of supersessionist antisemitism. ${ }^{2} \mathrm{ZU}$ has a particular need to appear to embrace that tradition, rather than seem decisively outside it, because of the book's substantially unqualified BDS-style denunciation of the Jewish state.

The reconciliation effort, however, includes several necessary components: breaking with the nearly 2000-year antisemitic supersessionist tradition in which Christianity declares itself the new Israel, with its covenant replacing the one Jews traditionally have with their god, confronting the long history of antisemitic Christian activism, including Martin Luther's implacable hostility to Jews, embracing the core message of love Jesus preached and honoring it in contemporary relationships, and

2 Nostra Aetate (“In Our Time”) (http://www.vatican.va/archive/hist_councils/ii_vatican_council/documents/vat-ii_decl_ 19651028_nostra-aetate_en.html) was promulgated by the Catholic Church in 1965 as one of the documents of the Second Vatican Council. It declares that Jews should not be presented as rejected by God and that Christ's crucifixion "cannot be blamed upon all the Jews then living, nor upon the Jews of today". "With this simple statement an entire theological edifice, built over centuries, collapsed" (Fisher 320). "It is easily the most significant document concerning Jewish-Christian relations in Church history since Paul in Romans 9-11. In 15 sentences it rejected anti-Judaic theological polemics and condemned antisemitism, and replaced them with the foundations for a renewed vision of the continuing role of the Jewish people in God's plan of salvation for all humanity" (Fisher 320). About the state of Israel, it should be noted, the Catholic church has retained considerable ambivalence. 
recognizing the unique and universal violence done to the human capacity for good and the escalation of the capacity for evil represented in the Holocaust.

$Z U$ is not altogether successful on any of these fronts. The problems with $Z U^{\prime}$ 's engagement with the Holocaust begin in the first chapter. The authors point out that both the Hebrew term for the Holocaust, Shoah, and the Arabic term for its collective tragedy in 1947-1948 when 750,000 fled or were forced out of the new Jewish state and lost their homes, Nakba, translate as "catastrophe". We do not need to treat these events as either equivalent or comparable to recognize that they are both catastrophes in their own terms, and that any given people will invest deeply in their own history and suffering. Palestinians generally see the Holocaust as a fundamentally European crime, not as a violation of basic human values for which we must all bear witness, though one might cite as evidence of Palestinian involvement the fact that the Mufti of Jerusalem was a Nazi ally and sought refuge in Berlin. The continuing Arab relation to the Holocaust is highlighted by the fact that, as Herf (2009) has documented in Nazi Propaganda for the Arab World, contemporary Arab antisemitism can be traced in part to World War II Nazi propaganda disseminated in the Arab world. The hatred of the new state that bloomed in 1948 and sent five nations to war against it thus owes something to Nazi Germany as well.

Matters are not helped in the ZU video series either. In the second episode, Ilan Pappe minimizes the Holocaust as merely "one of the worst genocides" and crudely tells us that "for the sake of its PR [public relations publicity] and to silence its critics Israel is willing to sell the victims of the Holocaust". While prime ministers Begin and Netanyahu have been sometimes willing to exploit the Holocaust for political purposes when it is not relevant, other leaders have not. It is a slander to level this accusation against Israel as a whole. That is what $Z U$ does when it declares that "Israeli politics are driven by actual and manipulated fear of annihilation (another Holocaust)" (p. 20). There are contexts in which fear of annihilation reasonably drives policy, including the concern that a nuclear-armed Iran represents an existential threat. But it would be absurd to claim Holocaust anxiety lies behind hundreds and thousands of Israeli policies or dominates the intricate and multi-faceted dynamic of its political debates.

ZU sanctimoniously urges that "no exceptionalist claims can be justified in our interconnected, pluralistic world" (p. 9). Despite the BDS movement's efforts to convince us that Palestinian suffering has a greater moral claim on us than that of any other contemporary people, one should certainly agree that "morally hazardous claims of a hierarchy of victimhood" (p. 9) are mistaken. Yet that does not mean that the historically unique character of the Holocaust, the Armenian genocide, or the century's other examples of mass murder should be erased, or that engagement with them should be geographically or culturally limited. That the Nakba was a tragedy is clear, but its more fitting comparison is with the large number of European refugees forced from their homes during World War II, not with genocide.

Trying to confuse claims about the unique character of the Holocaust with what amounts to a slander about the Jewish people that crosses a line into antisemitism, ZU asserts that "exceptionalism exempts the chosen from the need to conform to normal rules, laws, or general principles that we use to hold other people accountable" (p. 8). It is then an easy step to add a further accusation to the exceptionalist chain of equivalences: "The dark side of Zionist exceptionalism today is the ethnic cleansing and land confiscation of Palestinians justified by an appeal to God's will derived from biblical texts" (p. 8). While a tiny minority of Israelis are capable of making such arguments, most Israelis are secular and would never do so. Most Israelis consider the concept of chosenness an irrelevant anachronism. The status of the Jewish people as "chosen", furthermore, has long been distorted to mean superior or uniquely valued by God, rather than the original meaning of being chosen to embody and honor the burden of the law. As Reuven Firestone demonstrates, the three major monotheistic religions have all at various points in their history embraced versions of chosenness. For Christianity, claiming chosenness is a component of supersessionism and closely linked to the claim that Christians have replaced Jews and inherited the covenant with god. There is no basis for claiming that Israel 
justifies its policies by claiming it is a "chosen people". The argument crosses the line into antisemitism by suggesting Jews have a hostile sense of their own superiority over other peoples.

Equally fallacious, but perhaps more painful, is ZUs suggestion that the burden of responding to the Holocaust is exclusively a European one. Once you make that assumption, it is easy enough to conclude that when the Palestinians lost land they became "secondary victims of the Holocaust" (p. 6), despite the statement's offensive effort to blur the character of the Holocaust and diminish its effect on its true victims. Some of ZU's contributors both before and since its publication have expanded on the claim that the Palestinians are also Holocaust victims. In his 2017 book A Palestinian Theology of Liberation, Naim Ateek argues that "Palestine and its people were sacrificed on the altar of Western guilt" over the Holocaust, that "Palestinians were compelled to pay the price by their dispossession and loss of homeland," and that "One can even say that the Palestinians were the easy scapegoats" (p. 32). Characterizing the Palestinians as "scapegoats" for the Holocaust once again crosses a line into an antisemitic fantasy unsupported by historical fact.

For ZU to embrace that view on behalf of the Presbyterian Church is wholly unacceptable. It does not help that the text goes on to make a comparison between Zionism and Nazism, first noting that the theologian Paul Tillich "considered Nazism a false, secular alternative to prophetic Judaism and Christianity as it was based on pagan Teutonic myths of Aryan racial supremacy and was, in essence, a closed system with no room for the prophetic critique that the Hebrew Prophets and Jesus brought to humanity" and then immediately declaring Zionism as well "a closed system with little room for prophetic critique" (p. 38), an extraordinary claim in the light of the unrelenting prophetic critique that permeates the Jewish State. However irresponsible it is for individuals to promote a Zionism/Nazism equivalence, it is far more transgressive to prose it as church policy. Here, and elsewhere, ZU unfortunately follows the standard BDS strategy of treating Zionism as monolithic, whereas from its inception in the 19th century to the present-day Zionism has been both an evolving movement and a diverse one. One straightforward definition has, however, held throughout: Zionism is the belief that, after centuries of marginalization or persecution, the Jewish people should have a homeland of their own where they can have the opportunity to control their own destiny in the land of Israel.

The challenge $Z U$ faces in the light of Catholic and Protestant rejection of centuries of defining themselves in relation to a demonized Jewish other is to escape similar implications when they advocate for virtuous action in opposition to the purported depravity of a demonized Jewish state. They must free their hostility of any taint of antisemitism. But it is not so easy for Christian denominations, as they came into existence and established their identities in part through antisemitism. So, a cloud hangs over them. And ZU does not dispel this history simply by testifying early on to "the similarities between Zionism, South African apartheid, and Jim Crow segregation in the Southern US" (p. 18). In chapter 8, a condensed version of Mustfa Abu Sway's essay in Quest, we are reminded that "Racism is the cornerstone of the Zionist project" (p. 50). But the Anglican Reverend Naim Ateek, one of the authors of Kairos Palestine, gets the final word: "Zionism is a false theology" (p. 56). "From a Palestinian Christian point of view", it "is a retrogression of the Jewish community into the history of its very distant past, with its most elementary and primitive forms of the concept of God ... a narrow and exclusive concept of a tribal God" (p. 33). It "commits theological injustice by its appeal to God, history and race" (p. 57). ZU's numerous and varied attacks on Zionism do not help dispel the impression that traditional supersessionist antisemitism lurks behind the project as a whole.

3 The Kairos Palestine Document (http://www.kairospalestine.ps/index.php/about-us/kairos-palestine-document), published in 2009, was composed by Christian Palestinian representatives of several affiliations and represents the manifesto of the Christian BDS movement. Building on liberation theology arguments and theological political documents crafted by South African anti-apartheid activists, the Kairos Palestine Document defines Israel as the world's premier source of injustice and evil, simultaneously praises non-violence and advocates violent resistance to the Jewish state, and embraces multiple versions of anti-Israel boycotts. 
While attacks on Zionism have always been central to critiques of Israel, it is worth pointing out what special paradoxical status they have in IPMN's project. IPMN sees Zionism simultaneously as a secular movement manipulating religious Christians in traditional Protestant denominations and as a fundamentalist religious movement shaping Israeli policy and appealing to evangelicals. Central to the insistence that Zionism is fundamentally a religious philosophy, a theology, is the claim that it conceives the state of Israel as a "biblical entity" established in fulfilment of God's will. Of course, there are both Christians and Jews who believe that, some with fanaticism, but there are millions in both secular and faith communities who simply do not think in those terms. While $\mathrm{ZU}$ aims to discredit those confused "Christians who are not able to distinguish between biblical Israel and the newly created state of Israel" (p. 22), especially evangelicals, the focus on Zionism is also more broadly directed to $\mathrm{ZU}$ 's faith community. Framing the argument in terms of Zionism appeals to all those who think partly in terms of spiritual essences, including all those committed to some version of Christian eschatology. Moreover, treating Zionism as a transhistorical, essential belief system and political imperative speaks to those who imagine it is possible to recognize a nation's soul. Zionism is Israel, ZU's authors would have us believe, everything else about a diverse and notoriously disputatious country disappears before that reality.

These very basic errors are enhanced by what one may consider to be sloppiness enhanced by confirmation bias. In a few cases, $\mathrm{ZU}$ makes statements so divorced from reality that only people who know the relevant literature could possibly understand their source. A good example is the assertion that "Jewish life is alive and well in the Islamic Republic of Iran" (p. 48), a claim that Iranian propaganda promotes, but that has been documented as horrifically untrue. A community of over 100,000 in the late 1970s, Jews in Iran now number fewer than 9000. Their leadership is expected to condemn Israel, though false accusations that Iranian Jews are Israeli or US spies have nonetheless been promoted and led to executions.

More serious still is the document's promotion of the BDS affirmation of a full-scale right of millions of Palestinian descendants of the 1948 exiles to return to Israel within its pre-1967 borders. Since the Camp David Accords, it has gradually become clear that even the Palestinians involved in formal negotiations no longer make that demand, which would imperil the Jewish majority, but rather ask for a frank acknowledgement of Israel's role in the Nakba, a very limited right of return for those with immediate family members in Israel, and compensation for lost property. The BDS movement continues to make it an issue two decades after West Bank Palestinian leaders privately resolved the matter and moved on, despite public rhetoric to the contrary. It is true that Palestinian leaders have failed to educate their people about the necessity of this concession, but $Z U$ is not helping matters by misrepresenting the matter for their readers by treating a universal right of return as a necessary objective. Equally regrettable is $Z U^{\prime}$ 's implied endorsement of the view that the existence of a de facto single state encompassing the West Bank means that the two-state solution is dead. Faith communities would benefit from debating that issue, but not from a foundation that the matter is already decided.

At one point, $\mathrm{ZU}$ makes a powerful observation that is among the few statements here that could inspire a very different engagement with the Israeli-Palestinian conflict: "With Augustine's and Anselm's perspective in mind, the traditional view (that the life, death, and resurrection of Christ is 'the most complete revelation that God has yet granted humankind') claims more than any individual can know" (p. 30). Comparable doubt about (and willingness to question) the project's conclusions regarding the Jewish state could underwrite faith-based reconciliation efforts that would actually contribute to the search for peace.

$\mathrm{ZU}$ is decidedly vague about how and when reconciliation should actually play out in that process, but key texts from the Palestinian Liberation Theology movement, whose arguments are so central here, are more revealing. As Ateek (2017) writes in 2017's A Palestinian Theology of Liberation, "there are three essentials that must be realized in order for a genuine peace to be achieved: justice, peace, and reconciliation. The sequence is important" (p. 142). In other words, all reconciliation efforts are invalid until Palestinians secure full justice—on their terms—and peace has been achieved. But reconciliation 
is a process. It should begin now, but may not be fully realized until years after a peace agreement is implemented. That parallels BDS anti-normalization arguments against contact with Israelis on any basis that assumes equality between the parties and that is not based fundamentally on an Israeli admission of absolute responsibility for all injustice related to the conflict. But peace negotiations are not likely to succeed without sufficient reconciliation to achieve mutual empathy and respect for one another's historical narratives. During peace negotiations themselves, sufficient reconciliation to curtail mutual demonization will also be critical. And the negotiations will need to specify forms of economic and military collaboration based on a significant degree of reconciliation. If the implementation of an agreement is to be in stages, as is almost certainly the case, reconciliation will have to proceed in stages as well.

\section{Zionism and the Quest for Justice in the Holy Land}

Zionism Unsettled was the product of a 14-member project committee and group of writers, editors, and image researchers headed by Walt Davis. Other than Davis himself, none of the authors of the essays in Zionism and the Quest for Justice in the Holy Land appear on the list of those directly responsible for ZU. Presumably, that means none of the Quest authors save Davis himself condensed their own essays for publication in ZU. ZU actually appeared on 20 January 2014, five months before its source text, Quest, which was officially published July 1, though copies may have been available a few weeks before that. Unlike ZU, Quest thus likely had only very limited effect on the Presbyterian General Assembly's June 20 vote by a 310 to 303 margin to divest from three companies doing business in Israel and "profiting from the occupation" of the West Bank.

Readers of $Z U$ alone have no indication about the relationship between the two books or about what was left out of Quest in the process of editing it for its new life as ZU. Quest does include an unusual disavowal of editorial responsibility for fact checking: "The writers, not the editors, bear responsibility for the accuracy and interpretation of this (Israeli-Palestinian) history" (p. 2). Although that disclaimer is not repeated in $Z U$, it has effectively been invisibly grandfathered into the guidebook. But a comparison of the two publications is instructive. Quest not only fleshes out the positions held by ZU's authors, it also clarifies what strategy ZU's compilers had in mind in their campaign to influence church members and push the divestment agenda.

Some differences may seem straightforward. Carole Monica Burnett's Quest survey of Eastern Orthodox history and contemporary perspectives was likely judged less-critical and omitted, but the editors may also have preferred to avoid dealing with her intense anti-Israel hostility. She reads a series of ancient and contemporary theologians and religious leaders so as to marshal them for a condemnation of Zionism. Burnett excuses John Chrysostom's fiercely anti-Jewish sermons (pp. 386-87 $\mathrm{CE}$ ) as typical of the age's rhetorical excesses. While that is partly true, she ignores their unique, powerful influence on subsequent violence against Jews. Meanwhile she applauds early supersessionist arguments, such as that "Christ is the source of meaning, the raison d'être, of the Old Testament" (p. 97) or "the land grant to ancient Israel was tied to a particular era of history and is surpassed by salvation in Christ" (p. 98). Origen she finds particularly instructive for contemporary usage: "the spiritual significance of the Promised Land is that it symbolizes Christian perfection" (c. 212-215 CE) (p. 99), not any relationship between god and the Jews. Jerome (c. 393 CE) reinforces that reading: "the Old Testament 'land of promise' is the heavenly kingdom of God, not Palestine" (p. 101). Her language is carefully chosen to draw contemporary parallels. Thus Basil, Bishop of Caesarea, "condemned the practice of land seizure and home demolition committed by the wealthy against their social inferiors" (p. 101). She concludes the historical section of her essay by invoking the antisemitic trope of the greedy Jew: "the church fathers' affinity for symbolic interpretation of the Promised Land plus their abhorrence of greedy acquisitiveness, combined with their advocacy for the poor, add up to a patristic tradition that offers no support for the current Zionist perpetration of land seizure, expulsion of residents, and repopulation in the West Bank" (p. 102). 
Other Quest passages eliminated in editing $Z U$ reinforce the conclusion that they were deleted to make the guidebook somewhat less aggressive in its anti-Zionism and more palatable to a broad Presbyterian and interfaith audience. It is possible that some readers would, for example, have been still more offended by the Davis and Coffman statement that "a 'Jewish state' legitimizes racism and discrimination in favor of Jews in all areas of public life" (p. 47), by Sway's blunt declaration that the idea of "a Jewish democracy is an oxymoron" (p. 204), by Wagner's insinuation that there is a contemporary lesson in his reminder that "the Prophet Elijah once challenged the people of Israel who had chosen the pagan religion of Baal over the religion of the one true God" (p. 173), by Ateek's amplification of his characterization of Zionism as "a false theology", common to both books, with the outrageous claim that Zionism "promotes death rather than life" (p. 219), or by wider quotation of the rhetoric in Brant Rosen's original essay, as in such passages as "liberal American Christians have been theologically blackmailed into silence over Israel's human rights abuses" or his account of responses to the Kairos USA statement: "the Jewish Council for Public Affairs ... hysterically condemned its 'extreme rhetoric' and referred to it as a 'false witness'" (p. 88). What is missing from ZU is the charged modifier "hysterically". Rosen's key claim that Israel represents "the living embodiment of Judaism as empire" makes its way into $Z U$, but not some of the statements that underline the intensity of that claim, such as the characterization of Israel as an "overmilitarized garrison state" (p. 67) or "this quasi-Faustian bargain we have made with political nationalism" (p. 87). In a 2017 essay written for JVP's On Antisemitism, Rosen repeats the Faustian bargain claim without the "quasi" modifier, adding that Israel "commits human rights abuse at home and exports it abroad" (p. 134). Rosen, it should be remembered, was one of the most vocal supporters of convicted terrorist Rasmea Yousuf Odeh, despite her involvement in a 1969 Jerusalem supermarket bombing that killed two people.

Brant Rosen's chapter in ZU is one of three, along with those by Gary Burge and Abu Sway, that is presented in the form of a third person summary, rather than as a direct condensed version of the original essay. While it would be easy for readers to miss that difference, it gives the editors greater license not to represent the original essays fully. Thus, while the summary of Burge's essay is straightforward in demonstrating that he is promoting a supersessionist or replacement theology of his own, his claim that the "suspended blessing" of God's covenant with the Jews will be "restored at the end of history when Christ returns, when 'all Israel will be saved'" loses some of its edge when his assurance in Quest that Judaism "will join the church" (p. 189) is omitted.

For those who consult both ZU and Quest, the two texts amplify and complicate one another. That is partly a function of format. Quest is a conventional, unillustrated print book that offers extended argument. $\mathrm{ZU}$ is a complex bricolage, a mixture of signed and unsigned contributions, chapters and inserts, illustrations with independent and argumentative captions, sidebars, and study questions. There really is nothing quite like it either in the pro-BDS or anti-BDS literature. The bricolage format, almost that of a compressed, popular coffee table book, has the effect of multi-directional critique, a kind of extrajudicial triangulation of Zionism that leaves no escape from a guilty verdict.

It is almost as an aside that $Z U$ tells us "there is a growing consensus-except, notably, in the US and Israel - that the existing de facto one-state situation/solution is irreversible" (p. 23) and consequently that the two-state solution, the gold standard since 1947, is dead. There is no such consensus, though out of either warranted frustration or malice toward the Jewish state some maintain that only a single state from the Jordan River to the Mediterranean Sea with equality and justice for all can cure the disease of Zionism. That is a recipe for civil war, not a guarantee of equality and justice, but the appeal to a benighted humanism can seem persuasive to idealists both within and without faith communities. For readers persuaded by the $Z U$ project, one thing will be clear: Israel has so betrayed human value as to eliminate its very right to exist, and thus, the real problem with a two-state solution is that Israel would still be there. A solution that sustains the existence of a Jewish state is no solution at all.

As many advocates of a two-state solution point out, its fundamental outlines are clear: not "an end to Jewish settlements" (p. 22), as ZU unrealistically declares, but incorporation of those near the 1967 borders with Israel and evacuation of those deeper into the West Bank, not a full right of return 
to Israel proper for the few remaining living refugees and millions of their descendants, as the BDS movement insists, but return for a few and full compensation for losses for others. Two states for two peoples has been and remains the only route to justice for both peoples.

The paradox of a workable peace is that it will require not only a maximum degree of separation between the two peoples, but also a maximum degree of collaboration between them. The presence of violent agents among both Israelis and Palestinians requires modes of separation, including the much-demonized separation barrier, less than ten percent of which is actually a wall, the rest being a wire fence that can easily be rerouted as necessary. Collaboration should entail working together on security and on infrastructure needs, from water resources to drip-based agriculture to sanitary systems, and tens of thousands of additional Palestinians should get legal permits to work in Israel. The full list of areas of cooperation would be longer, its implementation, over time, could make it possible to tear down that wall. But not now. Meanwhile, Israeli government policy toward Gaza and the West Bank needs to be changed, with counter-productive practices like house demolitions eliminated, but that will most likely happen when Israeli citizens demand it.

In the end, the key response to the $Z U$ project necessitates not simply questioning its facts and interpretations, but rather asking what it contributes toward the options that faith-based movements have to make distinctive contributions to the peace process in the Middle East. Foremost among these are the many Christian efforts to promote empathy, mutual understanding, and reconciliation. ZU and Quest do nothing to promote those values. Instead, they relentlessly castigate and demonize the Jewish state, a rhetorical tactic which only pits the parties against one another in what amounts to a war of words and potentially antisemitic moral recrimination. Contrary to the BDS movement's claim, reconciliation does not lock in injustices, instead it provides the shared respect that is a prerequisite to overcoming them nonviolently. Faith-based constituencies everywhere have roles to play in promoting change from the bottom up. ZU and Quest go a different route. Perhaps the very clarity of their antagonism can help some make a different choice.

\section{Before and After Zionism Unsettled}

As the first section of this essay makes clear, Presbyterian debates over Israel and the Palestinians have a long history. Some of the principles underlying debates in the twenty-first century are codified in a 1980 General Assembly publication, Peacemaking: The Believers' Calling, which does not-except for a few sentences-directly address the Middle East, although it echoes church documents from the 1970s that do address it. There the church highlights one of the governing motivations behind support for Palestinians: "it is not possible to ignore the incongruous juxtaposition of affluence and arms on the one hand, and poverty and oppression on the other ... Our insensitivity to today's patterns of injustice, inequality, and oppression-indeed, our participation in them-denies the gospel" (p. 5). In multiple passages, we are told that "Concern about freedom and justice may well call for policies that side with the dispossessed" (p. 26). Belief that the Palestinians are the primary victims in the Israeli-Palestinian conflict was already present in the church by 1948-1949, although that conviction was long moderated by awareness of the Holocaust. Over time, however, the Holocaust receded in centrality for some Presbyterians.

Still more directly influential was the 2010 General Assembly report Breaking Down the Walls. Written by nine appointed members on behalf of the PC (USA)'s Middle East Study Committee, among its notable stands is its opening argument that invokes a broad humanistic opposition to "walls" in general and links it to Israel's security barrier, the first continuous segment of which was completed during the Second Intifada. "We are called to be those who break down these walls that stand in the way of the realization of God's peaceful and just kingdom" we are told at the outset (p. 1). The misguided application of an uninformed opposition to all barriers to free movement has guided the BDS movement's continuing demand that the wall be torn down, even though that would encourage violence, not peace. 
The policy document is then prefaced by eight "letters to our church, partners, and engaged parties" - the ecumenical community, American Jews, American Muslims, Middle Eastern Christians, Palestinians, Israelis, and all Americans. The letter to American Jews affirms that "we support the existence of Israel as a sovereign nation within secure and recognized borders" (p. 5). The letter to Israelis declares church members to be "strong advocates for Israel's secure existence" and says "we are fervent in our hope that Israel would continue to be a homeland for the Jewish people" (p. 9). The language, including the indefinite article "a", is carefully crafted to leave open the option of a one-state solution dominated by Palestinians. The other letters do not repeat these assurances, which seriously undermines any commitment they might embody. Worse still, however, is the document's endorsement and reprinting of both "The Amman Call" and Kairos Palestine. Kairos demands an unqualified Palestinian right of return, rejects the idea of a Jewish state, and castigates the West for making amends for "what Jews had endured in the countries of Europe ... on our account and in our land" (p. 74). Despite the PC (USA) in 2008 issuing a call for a more even-handed approach to the conflict, Breaking Down the Walls went so far as to lend legitimacy to denying Israel's right to exist as a Jewish state. It was condemned by the Anti-Defamation League, among others.

Four years later, the IPMN issued the influential Zionism Unsettled, a much more expensive undertaking. Breaking Down the Walls was a conventional printed text. $Z U$ was neither the first nor the last full-color, oversized book produced by IPMN in this distinctive format. Depending on how you count, it was either the second or the third, but it was certainly the one most widely publicized and debated. The aesthetic adopted for IPMN's full color books was basically visual, it requires much less reading, being devoted only to short texts interspersed with pictures.

Steadfast Hope: The Palestinian Quest for Just Peace (Israel/Palestine Mission Network of the Presbyterian Church (USA)), the first in the series, was published in June 2009, accompanied by a DVD. A second, somewhat revised edition, appeared in April 2011. The introduction to the 2011 edition reports that the first edition "was written in a spirit of guarded optimism", but that "those hopes were dashed". Now all "peacemakers" must confront Israel's "systematic discrimination against Arab citizens ... a bleeding, untreated wound inflicted in 1948". The authors write now with a "burning desire to speak to the Church with the unvarnished truth about this conflict". "The Church has been here before", they add, "and it is now awakening to the truth that God is calling it to be there again" (p. 1). Most of the chapters in the second edition of Steadfast Hope remain unchanged. The major change in the text is the addition of a detailed essay, "Post-Gaza: a new chapter in the quest for just peace" (pp. 36-39), which focuses on critiques of policies adopted by the Netanyahu government.

Two years after Zionism Unsettled was published, the PC (USA)'s Advisory Committee on Social Witness Policy (ACSWP) issued Israel-Palestine: For Human Values in the Absence of a Just Peace for the 2016 General Assembly. It was yet another long anti-Zionist report, this time produced by an official church committee. Since IPMN is a voluntary interest group, the church can claim its publications do not represent the PC (USA) or its views. The ACSWP report, on the other hand, displays the official church logo and is prefaced by the Stated Clerk of the General Assembly, declaring it was formally adopted as church policy in June. This time the PC (USA) cannot keep the text at arm's length.

The authors of the report unfortunately did not care to do adequate fact checking. Thus, they immediately tell us the First Intifada was "largely nonviolent" (p. 20), despite over 800 Palestinians having been executed as suspected collaborators with Israel. Hurling stones and Molotov cocktails was a standard demonstration tactic. Israel lost a hundred civilians and sixty Israel Defense Forces (IDF) personnel. Thousands on both sides were injured, and over a thousand Palestinians died. We are informed that "advocating for the 'two-state solution' or any other particular political arrangement has often distracted people from ongoing events and suffering" (p. 6). They inexplicably declare that East Jerusalem "under Jordanian control before 1967" was "accessible by all religious groups" (p. 18), but of course Jews could not even access religious sites like the Western Wall or the Temple Mount/Haram al Sharif. They tell us the Israeli blockade of Gaza is responsible for "causing lack of food security among much of the population", but all authorities, including Palestinians themselves, 
report that food supplies are adequate. The problem is that the poor cannot afford to buy food in stores, a problem exacerbated by the Palestinian Authority's decision to withhold Gazan income. When they acknowledge Palestinian hostility toward Israel, they qualify it in misleading ways, telling us, for example, that the "few" tunnels Hamas dug into Israel were only "purportedly dug to enable assault teams to attack Israeli border posts" (p. 29). Then they cast doubt on the claim Hamas's rocked attacks were "unprovoked" (p. 30). They condemn attacks on UNRWA (United Nations Relief and Works Agency) schools in Gaza without reporting that the schools intentionally targeted were used as weapons depots, making them valid targets.

On behalf of Presbyterians for Middle East Peace, Todd Stavrakos and Michael Gizzi produced "A Response and Rebuttal to the ACSWP Report", which is an effective and detailed counter to the entire project (Presbyterians for Middle East Peace 2016a). They begin by taking particular issue with the report's use of the term "Zionist Judaism" in a derogatory effort to suggest that Judaism itself has been corrupted by what ACSWP sees as political Zion's abuse of human rights. They add that "Speaking of 'tribal loyalties' with reference to Jews is code language used in the past and present to question the loyalty and fealty of the Jewish people in the states they reside" (p. 7). They point out that ACSWP "treats attacks on Israeli civilians as armed resistance, when they are really acts of terrorism" (p. 6). In a telling rejoinder to the report's sympathies with Hamas's willingness to treat Gazans as expendable, Stavrakos and Gizzi declare that "It is disturbing to find a Body of Christ offering legitimacy for such violence" (p. 13). One needs to add, finally, that a number of church members are active in both IPMN and ACSWP. They are intertwined political projects.

\section{Why Palestine Matters: The Struggle to End Colonialism}

Once again, the anti-Zionist forces in the church struck back. The third, entirely new addition to the IPMN book series, Why Palestine Matters: The Struggle to End Colonialism, a sequel to Zionism Unsettled, was issued in April 2018, just in time for PC (USA)'s annual meeting in June. The first publication in the series was Steadfast Hope: The Palestinian Quest for Just Peace. Toward the end of Why Palestine Matters, there is a decidedly improbable effort to extend the politics of intersectionality to include a link between Gaza and Puerto Rico in the aftermath of Hurricane Maria. The second item in "Parallels with Puerto Rico", "Letter from Gaza: 'We Are All Puerto Ricans,'” opens by declaring "I know what it's like to struggle with shortages of vital supplies such as electricity, gas, cash, and safe water" (p. 82).

Why Palestine Matters is a 110-page oversized book consisting of 39 essays, over 30 breakout supplements, and a large number of illustrations with full paragraph captions. It includes three very useful color maps, one each of Gaza, West Bank settlements, and West Bank Areas A, B, and C. The editors describe it as the third "study guide" issued by IPMN, but it is so fiercely one-sided that it really serves exclusively as an ideological and political manual for anti-Israel organizing rather than a neutral study guide. The volume connects with IPMN's history by once again explicitly aligning itself with the BDS movement, but this time doing so at length. Many of the essays are new, but a few are excerpts from earlier publications. In the latter category are Steven Salaita's intensely worded "Cultural Appropriation or Theft?" which warns us that use of the phrase "Israeli hummus" as a product label for the well-known appetizer amounts to "a project of erasure, a portent of nonexistence, a promise of genocide" (p. 61) and Sarah Schulman's "Rebranding with Sex and Sexuality", which reprises her 2011 brief against "pinkwashing", the purported effort to distract attention from the military occupation of the West Bank by highlighting Israel's gay-friendly legal and cultural environment.

The book's political stance is signaled at the outset not only by its subtitle, but also by its foreword by Richard Falk, a former United Nations Special Rapporteur on the situation of human rights in the Palestinian territories occupied since 1967 and one of Israel's most relentless long-term opponents. He concludes his assessment of Israel's history and present prospects by insisting that "negotiation of a sustainable peace depends on the prior disavowal and abandonment of the apartheid regime that Israel relies upon to subjugate the Palestinian people" and agreement "that any legitimate state or 
states that emerge in Palestine formally must be neither religious nor ethnic" (p. 8). A page earlier he had declared that "denying involuntary exiles a right to return to their native country is a grave violation of international refugee law" (p. 7). He envisions a full right of return for all descendants of the 1948 Arab refugees, 97 percent of the original refugees themselves by now being deceased. If the result were to be a majority Arab state, any promise that it would be a securely secular entity would soon be forgotten. A home for the Jews it would not be.

The page devoted to Puerto Rico follows many pages devoted to more familiar "intersections", including that promoted by a segment of the Black Lives Matter movement. An Israeli Defense Force/Hurricane Maria parallel, notably, is a completely empty analogy. Neither the two instances of infrastructural devastation nor the human tragedies they accompanied have anything to do with one another. An international relief effort could address urgent requirements in both places, but then what Puerto Rico needed was a serious full-scale commitment from the wealthiest country in the world, not international charity. I had expected the editors of Why Palestine Matters to base the case for the "intersection" of Gaza City and San Juan on underlying racism as the common cause. That certainly goes a long way to explaining the Trump administration's indifference to Puerto Rico's plight, but it has little or nothing to do with the Netanyahu administration's tragic and highly dangerous neglect of Gaza.

Why Palestine Matters appropriately places the 1901 US Supreme Court case Downes v. Bidwell at the root of the secondary status of the island, but that is not an adequate explanation of why Hurricane Maria did not provoke a new push for Puerto Rican statehood. The fact that the Island would vote reliably democratic has more to do directly with a Republican Congress's unwillingness to address its statehood status. The specifics of history can get squarely in the way of promoting "intersections" between injustices in different parts of the world. The editors print a photograph of three Puerto Rican women arm-in-arm with a Palestinian American San Francisco State University professor holding a "Mujeres en Puerto Rico/Solidarias con Palestine" banner and assure us that "Palestine solidarity is an enduring feature of Puerto Rican intersectional activism", but an "enduring feature" is not actually a central one.

Susan Landau's essay "Nonviolent Economic Action as Resistance", an essay that attempts to be a primer on the BDS movement, is illustrated with a photo captioned "The arrest of Rosa Parks on 1 December 1955, catalyzed the Montgomery bus boycott" (p. 86). This is a still more far-fetched intersection, since not only half the planet but also half a century separates the two movements. Indeed, Landau's essay doesn't invoke the American civil rights movement. Perhaps the editors chose the illustration hoping to trigger an emotional reaction. Some historical moments deserve their nearly sacred character as unique events. They cannot actually be honored by exploiting them for unconnected political purposes. Americans especially should not be called upon to think "Israel" when they see the moving photo of black demonstrators waving as the Alabama bus goes by. Israel critics and supporters alike should all be able to treasure that image, in a moment of solidarity purified of irrelevant contemporary conflicts.

Notice that intersectionality will be now be central to IPMN's and the book's effort to appeal to American readers comes with the introduction, which is titled "Intersectionality and the Shared Struggle for Human Rights". The "intersection" put forward there is not between any particular social or political circumstances but rather, in the style of BDS anti-Zionism everywhere, on the wholly abstract plane of universal justice: "Justice in one place is not enough without justice everywhere ... Scholars now use the term intersectionality for this interwoven web of rights and the common struggle to realize these rights all over the world" (p. 9). Yet these struggles have to be waged under local conditions and in the context of local politics and history. Invoking universal principles has genuine value in local struggles, but the struggle is not simply a universal one that can be transported intact across time and space. There is nothing scholarly about the term intersectionality used this way, it is merely a rhetorical platform, a persuasive strategy, not a category of scholarly analysis. It has become a slogan, a rallying cry that tries to transform analogy into identity. 
Used properly, intersectionality can be a powerful analytic tool. It helps us see how what appear to be separate social and political forces-like race and gender-intersect in a given place and time, combining to have a more powerful impact. But claims of intersection across time and space artificially link what are typically no more than partly parallel phenomena, obscuring the critical details necessary to full understanding. Claims that things happening in different cultures are actually identical can undermine the perspectives required for effective political action.

Contrary to what the book's editors would like people to believe, the project of human emancipation can be carried out in some places without being carried out in others. Indeed, that project would otherwise be an impossible one to wage. The introduction concludes by claiming the project of human emancipation "cannot proceed without Palestine", but actually, for better or worse, it can. Different struggles for human rights can inspire one another, one can learn from one struggle and try to modify its lessons so as to apply them elsewhere, but the work begins anew in a new setting.

The first chapter, "Palestine Through the Lens of Colonialism and Intersectionality", and the second, "An Intersectional Approach to Justice", then follow. Whether this was a good strategy for anti-Zionist advocacy in the Presbyterian Church USA (2010) remains to be seen. It represents established rhetoric on campus, but it leaves behind the theological ground that has been important in the churches, thereby completing a trend away from theology and toward politics among Protestant denominations debating the Israeli-Palestinian conflict.

Why Palestine Matters then throws its lot in with intersectionality in a far riskier and more thoroughgoing way. For the next section is comprised of four double-paged color spreads, eight full pages, all in the book's oversized 8.5 by 11-inch format. The four spreads: "Intersectionality: Threads of Connection", "Interconnected Struggles: Intersectional Politics Grounded in Effective Alliances", "Militarization, Repressive Policing: Unprecedented Connections Across Movements and Border", and "Cross-Movement Connections: Building a Global Movement for Justice", do not advance arguments or make a case for particular "intersections". They declare them with disconnected one-paragraph statements and an array of twenty-six color photographs and posters. At best it represents juxtaposition instead of intersection, jettisoning any sense of a debate within a religious denomination.

A key example of mere juxtaposition is the book's repeated effort to link the Native American opposition to the Dakota Access Pipeline with organized resistance in the West Bank and Gaza. The resulting confusion has no real bearing on Israel, but it does obscure the tragic and continuing history of Native American oppression and discrimination in the Americas, effectively exploiting the Native American story for use in the anti-Zionist agenda. The long effort first to exterminate and then suppress and marginalize Native Americans is a story that deserves its exceptional character. The willingness to discount both Native American culture and values is a part of that story that persists today. But any effort to resist the forces that conspired against American Indians in North Dakota has to focus on the political power wielded by the gas and oil industry and the political power wielded by the industry's Republican allies at the state and national level. Making this a story about manufactured "intersections" with Israel only dilutes and derails education and advocacy on this side of the ocean.

The prominence given purported solidarity with Native Americans in Why Palestine Matters is unsurprisingly, moreover, primarily part of the BDS movement's antisemitic racialized anti-Israel strategy. Why Palestine Matters offers no evidence that Jewish Israeli attitudes toward Arabs are fundamentally racist. With roughly 100 different essays, mini-essays, essay excerpts, and argumentative photo captions offering a jumble of varied sites of assertive opinion, the book operates as much by insinuation as by responsible argument. Nonetheless, when Jewish Voice for Peace Media Manager Naomi Dann tells us late in the book that the white supremacist Richard Spencer sees himself as "a white Zionist" and "might be right about Israel" she is drawing together antisemitic threads that have been woven throughout: "There is a disturbing alliance between Zionists and white nationalists in the White House these days, and it doesn't come from nowhere. There is a shared bedrock of anxiety about demographics and racist and Islamophobic fear of 'Arabs' that goes hand in hand with both worldviews" (p. 89). 
It is partly demographics that proves this accusation a slander. It is critical for the editors of Why Palestine Matters to remind us that the Jews who returned to Palestine in the late 19th and early 20th century were largely white and European, that fact is central not only to the racialized story the editors want to establish for Zionism, but also to their settler colonialist narrative. The truth that gets in the way of this story is that in the years after Israel was established as a state, some 800,000 Jews fled from often ancient communities in surrounding Arab countries to settle in Israel. The majority of Israel's Jewish population today, descendants of those exiles, are of Middle Eastern, not European, descent. Socio-economic gaps remain, but these Mizrachi Jews are critical to the coalition that brought Likud to power. Nonetheless, G. J. Tarazi insists that "the ruling elite in Israel today, are not Middle Eastern but are European settlers" (p. 12). Just to cite a few important counter-examples: In the 2018 Israeli government there were 21 ministers, of whom 8 are Mizrachi, 2 are mixed, 1 is Druze and 10 are Ashkenazi. Of the last 5 chiefs of staff of the IDF, 2 were Mizrachi (Mofaz, Halutz), 1 mixed (Ashkenazi), and 2 are Ashkenazi (Yaalon and Gallant), the chief of staff Gadi Eizenkot, is Mizrachi-both his parents are from Morocco.

The majority of Israelis are Middle Eastern, even more so when the 20 percent of Israeli Arabs are added to the mix. If the standard marker of the socially-constructed illusion of race is skin color, then Israelis and Arabs are indistinguishable. There is no lack of hostility to neighboring Arab countries in Israel, but that hostility is not racial in character. Making it seem so is nonetheless a useful anti-Zionist strategy.

So Israelis here are accused of a "racism 'of the heart,'" an "insidious racism that cannot be changed through public policy and laws" (p. 14): "The racial domination that took centuries to develop in the United States has been concentrated and accelerated in Israel and Palestine" (p. 14). Here, we cross the line into antisemitism in a dramatically new way for IPMN. Why Palestine Matters aims to convince us that "The treatment of African Americans in the United States and Palestinians by Israel is shockingly similar" (p. 15). Long-time Israel opponent Pauline Coffman concludes that "The situation eerily parallels White Nationalists in the US calling for limits on non-White immigration in order to maintain the demographics they prefer" (p. 71). "How do we connect the dots between US racism, white supremacy, and the issue of justice in Palestine" (p. 89), asks Susan Landau? We do so, the editors believe, by repeatedly announcing they are connected.

Tarazi presses this agenda further still by suggesting that, when we examine the status of Palestinians, "parallels can be seen in the history of slavery in the United States" (p. 13). The comparison is warranted, he argues, because they "used the Bible as a weapon" to subjugate others they considered "less than human". That view is readily substantiated for slavery in the US but is wholly unsupportable as a characterization of Israeli attitudes toward Palestinians. Both that claim and the antisemitic accusation that Israelis are engaged in genocide should have been excluded from the book.

Why Palestine Matters is on far better ground when it alerts readers to a growing crisis in Gaza, a position both I and many Israelis have been arguing as well for several years. Three essays-those by Jennifer Bing, Ron Smith, and Harry Gunkel—are devoted to Gaza, the latter combining extreme hostility to Israel with an eloquent plea: "in her illness and darkness, Gaza offers us her hand. How can we refuse it" (p. 45)? Excoriating Israel, the standard BDS response, will not actually help the situation by bringing relief to Gaza. Nor does Kathleen Christison's attack here on the reconciliation and dialogue initiatives that have been a hallmark of Christian contributions to the peace process ("Who's Afraid of Dialogue? Normalizing Oppression"). "These efforts", she writes, "tend to be feel-good projects that lull supporters and donors into an ineffectual complacency". Such "normalization", she adds, "concretizes the status quo, standardizes the dominance of the strong party over the weak party, the occupier over the occupied" (p. 60). In fact, the mutual understanding such projects generate is essential if peace negotiations are to proceed.

When Why Palestine Matters confronts Gaza, it is long on condemnation and short on practical recommendations. Bing's call "to end the cruel and inhumane blockade" (p. 42) is no help either. The blockade should be moderated, but, if it were simply lifted, Hamas would bring in serious 
offensive weapons and the military conflict would escalate. Egypt and Israel instead should combine forces to lift restrictions on exports from Gaza to help its economy. The US and other countries should press the Palestinian Authority to withdraw its effort to limit Gaza's electricity supply and carry out other assaults on Hamas. The fishing limit should be extended from six to at least fifteen miles. Meanwhile, Hamas repurposes reconstruction aid to rebuild its military infrastructure, starting with rebuilding its assault tunnels. But there are Arab countries that could manage reconstruction projects directly to prevent that from happening. International advocacy should focus on the practical steps that must be taken to improve conditions in Gaza. The Presbyterian Church could play a major role there, but Why Palestine Matters does not point us in that direction. Detailed promotion of the existing Christian projects to build mutual empathy and understanding can make a major difference. The misdirection of Christian effort may be IPMN's most damaging legacy.

\section{Presbyterians for Middle East Peace}

Participants in the PC (USA)'s 2016 meeting had a comprehensive report available that provided an objective, well-reasoned analysis of the Israeli-Palestinian conflict. The eighty-page booklet, Two States for Two Peoples: A resource developed by Presbyterians for Middle East Peace (hereafter Two States) is unlike the several IPMN products in every respect (Presbyterians for Middle East Peace 2016b). Two States is not written as a response to Zionism Unsettled-indeed, $\mathrm{ZU}$ is only mentioned once, taking exception to $Z U^{\prime}$ 's antisemitic characterization of Zionism as a "false theology" (p. 41)—though the PMEP booklet is designed to reeducate church members, counter the IPMN campaign, and repair the damage the boycott movement had done to the church's ability to contribute effectively toward peace and reconciliation.

Virtually nothing in the booklet qualifies as polemical, whereas almost everything in $Z U$ does. $\mathrm{ZU}$ bills itself as a study guide, then provides relentless indoctrination. Two States takes seriously its desire to be a resource by giving readers multiple objective area maps and such thoroughly neutral sections as one listing and explaining the various Israeli political parties and government structures. The PMEP document is scrupulous in its presentation of fact, even-handed in its treatment of Israelis and Palestinians, and consistently sound in its analysis. Contrary to IPMN's efforts to claim indigeneity for Palestinians alone, for example, Two States explains why "Both Jews and Palestinians are indigenous to the land, and both Jews and Palestinians have a history of immigration to the land" (p. 4). It does make judgments, reaching negative conclusions about both Hamas and the BDS movement, but even those judgments are measured, as when it assesses a BDS/IPMN tactic: "It is easy for an advocate to cherry-pick legal viewpoints to support a given agenda or vilify an opponent. This kind of debate does not move toward peace, rather 'it would only add an insoluble element to what is already an extremely difficult problem.' A reckless pursuit of 'justice' rather than a negotiated peace treaty between Israel and the Palestinians is actually an obstacle to peace" (p. 31). As PMEP would advise us in the 2018 supplement to "Two States for Two Peoples", "'justice' is a catchy term and easy to sell with little or even fraudulent information. (p. 27)". Instead, Two States first offers two guiding principles:

The rights, dignity, and aspiration of both Israelis and Palestinians must be honored and respected

- The course of action supported must be consistent with principles of universal human rights: the right of self-determination and democratic governance, the right to free expression and peaceful assembly, the right to a nationality, and the right to live in peace with neighbors

That neither Hamas nor the Palestinian Authority honor these principles is an inconvenience IPMN simply ignores. As a way to move forward in harmony with these principles, Two States endorses two passages from The Alliance for Middle East Peace:

- People-to-people encounters are an effective and necessary strategy to create such sustainable collective public support for peaceful mutual coexistence on equal grounds and reconciliation. 
- Support for civil society programs in the Middle East is one crucial way that the international community, U.S. Government, and private philanthropists alike can positively move the peoples of the Middle East toward peace.

Of course, BDS and IPMN reject these options as examples of unacceptable "normalization".

As Reverend Chris Leighton, at the time Executive Director of the Institute for Christian and Jewish Studies, writes, ZU "turns us from peacemakers to polemicists", he writes, "and from honest dialogue partners to partisan ideologues ... The authors go to great lengths to document the worst expressions of Zionism and the American Jewish community, while completely exonerating the Palestinians from any ideologically driven teaching that fails to promote peace ... To suggest that the Jewish yearning for their own homeland-a yearning that we Presbyterians have supported for numerous other nations-is somehow theologically and morally abhorrent is to deny Jews their own identity as a people ... The word for that is 'anti-Semitism'"

In 2018, PMEP published "Two States for Two Peoples 2018 Supplement" (Presbyterians for Middle East Peace 2018), a forty-page update and elaboration on the previous publication. Early on it describes BDS as a movement "whose leaders have called for the elimination of the Jewish state of Israel while recruiting followers on the premise that BDS is nothing more than a human rights campaign" (p. 4). Among the important additions to our understanding that Two States makes is a section describing the Palestinian assaults on freedom of speech and press freedoms in Gaza and the West Bank (pp. 7-8). Two States also makes a strong case for strengthening the Palestinian Authority's governing capacity as part of a nation-building process necessary for creating a viable Palestinian state. As part of that discussion, the pamphlet conducts a serious review of concepts of sovereignty and how they apply to a potential Palestinian state. The scholarly character of this analysis has no equivalent in any IPMN publication. Its citations to previous scholarship reinforce the sense of the project's objectivity.

PMEP's important work gives Christians of all denominations a rational alternative to the hostile disinformation that BDS allies within the churches have been disseminating. Both sides in this debate invoke longstanding Christian values in their support, but justice and reconciliation lie more fully in the good faith PMEP has offered than in the hostility and alienating condemnation flowing from the other side.

The Presbyterian Church has had a dual track history regarding the Israeli-Palestinian conflict for half a century, but that means some in Church leadership have long offered exemplary advice, understanding, and mutual respect. They know how to advance reconciliation directed not toward submitting to an unacceptable present but toward a future two-state solution that would assure dignity and security for both peoples. The clearest earlier evidence may be the remarkable 1973 book Peoples and Conflict in the Middle East, hereafter PAC.

Offering an assurance categorically at odds with the IPMN/BDS publications, PAC concludes by reasserting to readers that the church "does not wish to be understood as preaching moral obligations to the nations concerned with Middle Eastern issues, in the light of centuries of antisemitism and particularly of Western treatment of the Jewish people in this century, and in the light of the long history of Crusades and colonial subjugation of the Arab peoples" (p. 51). PAC opens with a parallel principle, one of several here that counter the BDS anti-normalization campaign: "The task force specifically rejected any attempt to judge between the parties involved in the Middle East as to which has been dealt with most unjustly. The cup of suffering caused by displacements, pogroms, crusades, and holocaust is full. Solution must be found at some level beyond the attempt to weigh the suffering of one people against that of another" (pp. 8-9).

Moving forward, they advise, "we do not believe advance can be made without conversation" (p. 9). In an observation no less true now than it was fifty years ago, $P A C$ recognizes that a productive dialogue "demands a higher respect for the faith, traditions, sufferings, accomplishments, and even the myths of the contending parties than either is now willing to grant the other... It requires that all parties ask the questions that can make the future and not only those which would remake the past" 
(p. 10). "The tragedies of the past cannot be ignored", they add, because "the past is a part of the blood, bone, and soul of the peoples of the present, "yet "neither can the future be made of "those tragedies (pp. 10-11). The goal is productive reconciliation, which "can never succeed in winning agreement from those who believe that the definitive humiliation of one or another of these Middle Eastern peoples is essential" (p. 11). The IPMN/BDS agenda is grounded in the effort to achieve the definitive humiliation of the Jewish state. Happily, the church can use select documents from both past and present to guide it in promoting the reconciliation that is its true Christian mission. PAC states the matter clearly: "The way to peace, there as here, lies not through partisanship and polarization but through reconciliation Shalom Salaam" (p. 10).

\section{Conclusions}

The conflict between PMEP and IPMN has its parallel in a number of mainline Christian churches. Thus, for example, by the time the 200,000-member British Methodist Church, which had voted to endorse the boycott of settlement products in 2010, was in the process of considering more aggressive policies, the larger church was already considering such moves. Central to that effort was the large anti-Zionist book Israel-Palestine: A Mission Study for 2007-2008, which was published on behalf of the United Methodist Church's Women's Division within its General Board of Global Ministries. Meanwhile, the United Methodists for Kairos Response (UMKR), a product of a grassroots movement of Methodist clergy and laity, was initiated in October 2010 by a group within the UMC and reaffirmed in 2018, with an accusation that Israel's Nation State law codified an apartheid legal system. It has consistently asserted that the occupation is the major threat to the Christian presence in the Holy Land. On the other hand, a member of United Methodists for Constructive Peacemaking in Israel and Palestine declared "we are not going to participate in the continuing demonization of one side over the other or the continuation of policies that bring about fear and isolation for one side over the other" (Richard Horowitz). As with the Presbyterians, Methodist advocacy has coalesced into competing groups.

Israel-Palestine: A Mission Study for 2007-2008 is divided in two parts-a long essay (pp. 6-127) by Stephen Goldstein, a Jew who converted to Christianity, and a "study guide" (pp. 129-213) by Sandra Olewine (Goldstein and Olewine 2007). Goldstein tells us the outlook of the Jews who settled in Palestine was "basically racist, and still is ... they do not see Palestinians as human beings like themselves" (p. 32). The arguments put forward parallel those offered by IPMN, but each anti-Zionist church group also has its own strategies. Thus, Olewine tells us "we are called to see the places where Christ is still wounded, even crucified, through the pain and struggles in people's lives today" (p. 131), a familiar trope, but then mounts an unusually elaborate way of reinforcing the analogy. Following a series of sections summarizing the life of Jesus, she leaps two thousand years to the present in the section titled "Who Will Roll the Stone Away?" Christ is once again today being prevented from rising. None of us can be redeemed while Israel has placed a boulder that blocks the entrance to his tomb. It is a deeply religious and theological accusation, fundamentally antisemitic in character. She has retold Christ's story not only to give her own narrative credibility, but rather to abandon analogy for identity. There are good Jews who want to move the stone, but can they? Israel's weight is against the stone.

As this analysis has shown, the passions that drive BDS allies in secular groups have led Christians as well to use antisemitic tropes and rhetoric. Unfortunately, the consequences in Christian denominations are arguably more serious. That is because, despite the legacy of Christian antisemitism, there are alternative church traditions that could be employed in the service of peace. Churches have substantial experience in reconciliation initiatives that should be expanded to bring more Israelis and Palestinians into dialogue. Contrary to BDS claims, such efforts do not harden the status quo in place. Instead they reinforce the empathy, trust, and mutual understanding that are necessary for nonviolent change. The mainline Protestant denominations that have joined the effort to demonize Israel are thus undermining the special contribution Christian groups can make toward the resolution of the 
Israeli-Palestinian conflict. That is why all of us, both within and outside the churches, need to know about these developments and become prepared to address them.

Funding: This research received no external funding.

Acknowledgments: My thanks to Ethan Felson, Gunther Jikeli, Zachary Schaffer, Raeefa Shams, and Avi Weinryb for their suggestions about this essay.

Conflicts of Interest: The author declares no conflict of interest.

\section{References}

Ateek, Naim. 2017. A Palestinian Theology of Liberation: The Bible, Justice, and the Palestine-Israel Conflict. Maryknoll: Orbis Books.

Carroll, James. 2001. Constantine's Sword: The Church and the Jewws. New York: Houghton Mifflin.

Commissioners to and Observers of the 221st General Assembly of the PC (USA). 2014. Reformed and Reforming: A Word of Hope. n.p.

Fishman, Hetzel. 1973. American Protestantism and a Jewish State. Detroit: Wayne State University Press.

Goldstein, Stephen R., and Sandra Olewine. 2007. Israel-Palestine: Mission Study for 2007-2008: Study Guide. New York: Women's Division, General Board of Global Ministries, The United Methodist Church.

Herf, Jeffrey. 2009. Nazi Propaganda for the Arab World. New Haven: Yale University Press.

Hopkins, Paul A. 1990. American Presbyterians and the Middle East Conflict. American Presbyterians 68: 143-65.

Israel/Palestine Mission Network of the Presbyterian Church (USA). 2011. Steadfast Hope: The Palestinian Quest for Just Peace, 2nd ed. n.p.

Israel/Palestine Mission Network of the Presbyterian Church (USA). 2018. Why Palestine Matters: The Struggle to End Colonialism. n.p.

Israel/Palestine Mission Network of the Presbyterian Church (USA). 2014. Zionism Unsettled: A Congregational Study Guide. Available online: http://new.israelpalestinemissionnetwork.org/component/content/article/70/ 256-zionism-unsettled (accessed on 12 March 2016).

Jewish Voice for Peace, ed. 2017. On Antisemitism: Solidarity and the Struggle for Justice. Chicago: Haymarket Books. Morris, Benny. 2008. 1948: A History of the First Arab-Israeli War. New Haven: Yale University Press.

Presbyterian Church USA. 2010. Breaking Down the Walls. In The Report of the Middle East Study Committee as Approved by the 219th General Assembly. n.p.

Presbyterians for Middle East Peace. 2016a. A Response and Rebuttal to the ACSWP Report (by Todd Stavrakos and Michael Gizzi). Available online: https:/www.pfmep.org/163-222nd-general-assembly/184-a-response-andrebuttal-to-the-acswp-report-israel-palestine-for-human-values-in-the-absence-of-a-just-peace (accessed on 15 September 2016).

Presbyterians for Middle East Peace. 2016b. Two States for Two Peoples, A Resource Developed by Presbyterians for Middle East Peace; PFMEP. Available online: https://www.pfmep.org/images/stories/PDFs/TwoStatesforTwoPeoples. pdf (accessed on 17 June 2017).

Presbyterians for Middle East Peace. 2018. Two States for Two Peoples 2018 Supplement 2018; PFMEP. Available online: https://docs.google.com/viewer?url=https\%3A\%2F\%2Fwww.pfmep.org\%2Fimages\%2FPFMEP_ Homepage\%2FTwo_States_2018.pdf (accessed on 16 June 2018).

Wagner, Donald E., and Walter T. Davis, eds. 2014. Zionism and the Quest for Justice in the Holy Land. Philadelphia: Casemate Publishers.

(C) 2019 by the author. Licensee MDPI, Basel, Switzerland. This article is an open access article distributed under the terms and conditions of the Creative Commons Attribution (CC BY) license (http://creativecommons.org/licenses/by/4.0/). 